\title{
ЖАК ПРЕВЕР
}

Када се одмах после рата, 1945. године. појавила прва Преверова збирка песама Речи (Paroles), постигла je, за једну књигу поезије, незапамћен успех: за врло кратко време продато је 150 хиљада примерака. Од смрти Виктора Игоа, од осамдесетих година XIX века, Француска није имала свога истински народног песника, песника чије ће дело подједнако волети и рафиновани љубитељи поезије и људи скромна образовања. Добила га је у Жаку Преверу.

Мада се знатно скромније Преверово песничко дело тешко можц поредити са Игоовим поетским океаном, поред многих оштрих разлика постоје и извесне сличности које прилично објашњавају популарност оба песника. Пре свега, и Превер је, као и Виктор Иго, мајстор речи. Свака реч код Превера задржава своју звучност и боју; чак и најовешталијим речима и изразима он успева да врати првобитну свежину. У Преверовој речитости и лакоћи у низању неочекиваних песничких слика има нечег од игоовске реторике и необуздане инвенције. Кад се томе додају приврженост оба песника вечним темама поезије (љубав, слобода, туга, радост), а нарочито заједничко интересовање за време у коме живе и искрено саучествовање са свима који пате, онда су ту све особине које су, чини се, главни предуслов да песника прихвати широка читалачка публика. Ту и престаје сличност између Превера и Игоа - у осталом су они врло разли- 
чити. Додуше, и Иго и Превер су склони патетици, али док је Иго романтичарски необуздан, Превер се труди да осећања прикрије хумором.

Сличности измеду Игоа и Превера представљају, изгледа, константе популарне поезије; разлике између њих су разлике у сензибилитету две епохе. Иго је најчешће озбиљан и свечан, Превер оран за шалу и ироничан, али и нежан. У времену у коме постоји стална криза вредности тешко да би поезија игоовског типа, то јест поезија која непоколебљиво верује у себе и у свет, поезија песника пророка, могла да има велику популарност. Шта је, дакле, ново донела Преверова поезија те је била тако одушевљено прихваћена?

Покушаћемо да одговоримо на ово питање, а исто тако, и да испитамо разлоге његовог трајног успеха не само у Француској, већ и у читавом свету. Време је строг судија и многа још јуче у звезде кована дела већ су заборављена, а Преверове Речи ни после седамдесет година ништа нису изгубиле од своје непосредности. Данас се више не може сумњати да је Жак Превер велико име француске поезије.

И поред резервисаности великог броја критичара, од којих се неки и врло неповољно изражавају о Преверовом делу, неколико врло значајних критичара и песника имају високо мишљење о Преверовој поезији. Гаетан Пикон (Gaétan Picon) у својој већ класичној Панорами нове францнске книжвносли пише:

„Поезија Жака Превера [...] не може се упоредити ни са једном другом: читалац навикнут на алхемије модерне поезије чује овде нов језик [...]. То је помало као да смо, пошто смо дуго боравили у мрачним и скупоценим одајама већ стогодишњег музеја, најзад почели да удишемо ваздух улице.» ${ }^{1}$

1 Panorama de la Nouvelle littérature française, Gallimard, 1960, стр. 228-229. 
И доиста, Превер у потпуности одбацује традицију интелектуалистичке, херметичне и елитистичке поезије чији су најистакнутији представници у XX столећу Пол Валери, а у XIX Стефан Маларме. Преверови духовни преци су песници човекове радости и јада, Ритбеф (Rutebeuf), велики Вијон, и код нас мало познати мајстори песничког хумора Шарл Кро (Charles Cros) и Алфонс Але (Alphonse Allais), али и многи анонимни и мало познати аутори народних попевки. У Преверове духовне претке можемо још уврстити и ненадмашног мајстора вербалне инвенције, Раблеа, и мајстора ироније и персифлаже, Волтера. Жорж Батај (Bataille) сматра да је „поезија Жака Превера, управо зато поезија што представља живи деманти - и исмевање - онога што скамењује дух у име саме поезије. [...] Јер оно што јесте поезија, јесте и догађај у животу саме поезије, која је исмевање поезије. Тако је поезија Жака Превера поетична, не као Боалоово дело, које је песничко само по римама и ритмовима.[...]. Она је поезија јер у самој себи опоро обавља рушење поезије.» Преверова поезија је, дакле, и по Батају, као и по Пикону, дубоко оригинална, модерна и нова. Уз ова два мишјјења најугледнијих критичара наведимо и речи два велика песника, Ремона Кеноа (Queneau) и Андреа Бретона. За првог Превер „није само брат него и учитељ”, а за другога „он суверено влада скраћењем које је кадро да нам у тренутку пружи све осећајно и блиставо поступање детињства и у бескрај снабдева резервоар побуне". вер не воли да говори ни о својој поезији, ни о поезији уопште. На питање у једном интервјуу ${ }^{5}$,„А шта је са пое-

\footnotetext{
2 De l'âge de pierre à Jacques Prévert «Critique», $N^{\circ} 3$, août-septembre, 1946, стр. 199.

3 «Parler», décembre, 1965.

4 Исто.

5 «L’Express », 14. mars 1963.
} 
зијом?” он одговара: „Знате, поезија је постала реч коју сви мисле да разумеју, као, 'еротизам', 'комплекс', 'гег,' 'књижевност'... Сви кажу да су у току... У ствари, поезија, метафизика, то је као мода, час се носе дугачке идеје, час се носе кратке... А ето, увек има песника."

У Преверу нема ничега од народног трибуна, а још мање од књижевног мандарина. Он не сматра да је песник изузетно биће, већ део уличне вреве која је у исти мах и врева живота. песник је зачуђени путник, репортер који бележи лепе и ружне ствари живота, одушевљава се и негодује, али никад не моралише. Међутим, он будним оком прати шта се око њега збива. Превер је изванредан пример ангажованог песника који је успео да не прекорачи ону опасну границу која дели поезију од памфлета. Сиромашно дете париског предграђа, принуђен да се од своје петнаесте године сам издржава, он је, природно, на страни потлачених - био је један од њих. Зато се он већ у једној од првих објављених песама Покушај описа једне вечере главешина у Паризу - Франиуска (1931), обрачунава са моћницима овог света који брину само о себи и својим профитима, не обазирући се на беду која их окружује. Ова снажна песма не би била штампана да је нису препоручили, тада већ познати песници, Леон-Пол Фарг и СенЏон Перс. Крваве 1936. године, када почиње грађански рат у он» Подигнута палица, у коме приказује заверу сила зла против слободе шпанског народа. Користећи се филмском техником низања слика и смењивања планова, Превер гради своју драму. Остају у сећању упечатљиви карикатурални портрети папе и Мусолинија; свој драмски врхунац ова оптимистичка трагедија достиже у опису борбе за живот рањене птице, којим се завршава овај оригинални „фељтон». Шпанија и њена трагична судбина су присутне и у многим песмама у којима је основна инспирација друкчија. 
Тако у Пикасовој чаробној тампи налазимо минуциозни портрет чудовишног каудиља и опис срушене Гернике. Ни у зрелим годинама Превер неће остати равнодушан пред неправдом. У песми Чујете ли, тьди Вијетнама, објављеној 1953. године, користећи се ритмом и речима Марсељезе, подсећа своје сународнике, потомке револуционара, да су преузели улогу тирана. Вешто супротстављајући слике људских радости и призоре рата, он саркастично прича историју француске колонизације Индокине. Уопште узев, слике рата нису ретке у Преверовим песмама и халуцинантне су као Гојине гравире. За Превера, у ионако апсурдном свету, рат је највећа глупост и бесмисао. У Барбари, једној од најлепших песама, рат се појављује као метаморфоза кише над срећним градом у пљусак огња, крви и челика над рушевинама:

Сети се Барбара

Киша је лила над Брестом оног дана

О Барбара

Над Брестом киша непрестано тије

Као што је некада лила

Све је разорено

Ништа ко пре није

Страшна киша све је у ирно завила

Нема чак ни буре

Гвоздене крваве

Већ облаци јуре

Да ко псине свисну

С кишом изнад Бреста

Иструну нестану

Уморском бездану

Далеко од Бреста

Који и сам неста. ${ }^{*}$ 
У песми Време коштии $a^{6}$ песник жестоко напада милитаризам, који остаје да живи у људима иако су већ доживели један страшан рат:

Упозоравам вас стариии упозоравам вас главе породица

време када сте своје синове давали отаибини

као што се даје хлеб голубовима

то време се неће вратити више

деиу коју сте на својим леђима носили

гурнули сте у блато тробојно

у масну глину гробъа војног

Изванредно једноставна а снажна песма под насловом Породична буди у читаоцу осећање револта зато што људи рат прихватају као део своје судбине: реченица „они мисле да је то сасвим природно» понавља се као рефрен. Буђење уз фанфаре представља визуелни доживљај бојног поља који подсећа на надреалистичка платна једног суровог Далија. У овој песми рат је потпуно демитификован, јер је приказан као голо убијање и ружно умирање. Ту исту, овај пут историјску демитификацију налазимо и у песми Enoneja. Уместо апологетске и идиличне слике Наполеоновог похода у стилу једнога Гроа (Gros), имамо надреалистичку црнохуморну бурлеску са царевим инвалидом чије се ноге шетају

Тамо у историји

Свака за себе

А кад се сретну

Оне се ударају

Pam je pam

Шта се ту може.

6 *Све цитиране песме превео је аутор текста Р. Константиновић Ироничан наслов који асоцира на популарну француску песму Време трешана. 
Суморно виђење рата добија трагичне акценте нарочито кад песник говори о Другом светском рату. Бруталност окупације Превер доживљава као силовање (Нови поредак), или као монструозни злочин (Кључеви града). Окупација је као болест, као пошаст која хара драгим Паризом чије су љупке четврти једва препознатљиве (Улица Биси данас). У позадини догађаја назире се силуета једне мрачне личности. То је „бледи старац», маршал Петен, који је и издао Француску прихвативши сарадњу са Немцима, то је човек који држи умирујуће говоре док јеврејску децу одводе у логоре смрти (Sancta senilitas). Превера нарочито погађа судбина јеврејске сиротиње, качкетара и ситних занатлија из Улице Розје, који су, бежећи од прогона, мислили да су у Француској нашли уточиште и другу отаџбину, а њихови земљаци, сарадници окупатора, предали су их Гестапоу.

Преверу су антипатични сви они који изазивају рат или се на рачун туђе несреће богате, а велики освајачи буде у њему само презир. Отуд су Луј XIV и Наполеон честа мета његовог уништавајућег хумора. Луј XIV, „краљ Сунце”, добија сунчаницу зато што се погледао у огледало, а Наполеон је у многим Преверовим песмама приказан изразито негативно - као нека врста опасног лакрдијаша који је лаковерне водио у пропаст.

Превер нема милости за десницу, за њене политичаре, писце, њене светиње. Песници Пеги (Péguy) и Клодел због свога милитантног католицизма, а нарочито Пол Дерулед (Déroulède), аутор Војникових песама, због свог милитаризма и реакционарности, предмет су Преверовог подсмеха. То највише долази до израза у Преверовим сатиричним скечевима и једночинкама, писаним за позоришну групу „Октобар» (којој и сам припада). Превер и његови другови организују бесплатне представе за раднике у време великих штрајкова тридесетих година. 
Од самог почетка Превер је чврсто везан за јакобинску, републиканску, антиклерикалну и демократску традицију, која има дубоке корене у француском народу. Отуд и његов критички став према католичкој цркви, свештеницима и вери. У песми Оченаш Превер моли Бога да остане где је, „а ми ћемо остати на земљи која је понекад тако лепа». Божанском моралу он пркосно супротставља људски, небеском блаженству лепоту Земље, са свим њеним противречностима.

Преверов антиклерикализам има више узрока. Неки од њих су личне природе. И отац и мати понели су најружније успомене из детињства проведеног у интернатима које су држали калуђери, а и сам песник није могао имати добро мишљење о побожним католицима које је гледао кроз свог деду и бабу по оцу, Огиста и Софију Превер. Строги, хладни и пуни предрасуда, они су маломе Жаку нашли учитеља веронауке по свом укусу, а резултат тога је била дечакова потпуна одбојност према религији. Међутим, други разлог Преверовог антиклерикализма знатно је дубљи, филозофски. Превер је уверен да је религија један од облика опресије. Он одбацује и сам појам греха, па према томе и искупљења. У извесном смислу, Превер је Паскалов антипод: уместо да буде „мислећа трска», да за истином „трага уз плач», Преверов човек је ведри хедонист који у пуној невиности ужива у лепим странама живота.

Мисао, по Преверу, води човека понекад на странпутицу. Он има више поверења у човекове добре нагоне. Крајње неповерљив према метафизици, Превер с подсмехом говори о трансценденталности, зазирући од крупних и неразумљивих речи, као од подвале људима који живе као што дишу, једноставно. Већина критичара је запазила да се Превер углавном негативно односи не само према религији, већ и према традицији, ауторитетима, конвенцијама. Међутим, 
нису у праву они који га проглашавају анархистом, јер његова побуна против света није политичка, већ песничка, побуна у име апсолутне слободе која се у песниковој свести поистовећује са поезијом. Без антиконформизма, Преверова, и уопште, ангажована поезија свела би се на стиховану публицистику. Поезија мора да садржи довољно непоштовања табуа, јереси, светогрђа, да би читалац доживео катарзу, прочишћење.

Преверова поезија је сва у знаку неконформизма, али није нихилистичка. Јер, ако Превер не воли речи „вера» и „отаџбина», то не значи да ни у шта не верује. Напротив, Преверова поезија је, као ретко која поезија нашег времена, пуна искрене вере у људску топлину и солидарност, каткад готово детињски пуна поверења у људе, у љубав. Љубав је за песника мост ка поверењу и предуслов среће, а срећа је тренутак садашњости за који не постоји ни прошлост, ни будућност. У Преверовом великом љубавном циклусу нема места ни за љубомору ни за ситничавост. Љубави је, по Преверу, страно свако осећање припадања или обавезе. Она мора бити апсолутно слободна да би трајала. То је смисао песама За тебе, тьубави и Тамничареве песме. Лепи тамничар оставља својој драгој слободу чак и другога да воли. Превер, коме је страна свака мистика, верује н два чуда - чудо љубави и чудо лепоте. Љубав је необјашњива, слична заслепљујућем блеску или заглушном звуку. Са Преверових љубавних сцена скинуто је проклетство греха и у наготи жене, о којој он радо пева, поред лепоте, има и неке дирљиве чедности. Многе његове љубавне песме личе на старе народне баладе и показују колико је његов снажни песнички таленат кадар да речима и стварима врати њихов првобитни сјај. Утицај старе француске народне песме је благотворан. Тај утицај долази до њега и посредно: преко шансоне, која у ствари наставља традицију француске лирске народне песме. Јер, не забо- 
равимо, Жак Превер је један од најчувенијих француских аутора текстова за шансоне (Увело тишће).

Нема сумње да је Преверова поезија снажно утицала на француску шансону. Великим делом захваљујући њему, шансона је еволуирала од сентименталне или фриволне песмице из двадесетих година до садржајно и музички богате песничке шансоне, која доживљава свој блистав успон већ у првим послератним годинама. И истакнути песници не само да не сматрају светогрђем, већ се и поносе тиме да њихове песме буду извођене као шансоне (Арагон), многи пишу речи за шансоне (Кено) и - што је најзначајније - неки професионални извођачи, који су и аутори текстова и музике за своје шансоне, јесу аутентични песници. Зато није случајно што је песник и издавач Пјер Сегерс (Seghers) у својој чувеној едицији „Данашғи песнищи” посебне књиге посветио Жоржу Брасенсу (Brassens), Леу Фереу (Ferré) и Жаку Брелу (Brel). Преверове песме, нарочито оне које је компоновао Жозеф Косма (Kosma), пронеле су славу француске шансоне широм света. Томе успеху много су допринели и изврсни извођачи: Ањес Капри, Жилијет Греко, Ив Монтан, Жермен Монтеро, Кора Вокер, вокални квартет „Фрер Жак”, али је пресудну важности имало то што су Преверови текстови увек поседовали неуобичајен драмски набој, који Преверове песме чини изузетно подеснима за сценско извођење.

Преверово виђење света намерно је црно-бело, манихеистичко. У њему се људи деле на добре и зле, на оне које волимо (њима говоримо ти чак и ако их не познајемо, каже песник) и остале. У категорији осталих издвајају се „они” које у Оченашу песник назива легионарима несрећа. Свет оних које песник воли пространији је, гушће насељен него свет оних других. У свету првих налазе се сва деца, животиње, реке, заљубљени, заточени, напаћени, уморни или весели. У томе великом 
свету целе наше планете (песник је са љубављу гледа како се врти у космосу) нема места било каквој ускогрудости, звала се она расизам или шовинизам. У песниковом речнику нема речи отаџбина само зато што су му пиринчана поља Азије исто толико блиска као и обале Бретање. У наше време, у коме има још много расне мржње и ксенофобије, дирљиво звучи песма Чудни странци. Превер с пуно љубави говори о невољницима који су из разних крајева света дошли у Француску трбухом за крухом:

$$
\begin{aligned}
& \text { Чудни странци ви сте из овог града } \\
& \text { ви сте део юеговог живота } \\
& \text { чак и кад се зато раздирете } \\
& \text { чак и када од тога умирете. }
\end{aligned}
$$

Несхваћена, и деца су нека врста странаца у једном за њих непријатељском свету. Детињство је једно од великих тема Преверове поезије. Дететова беспомоћност буди песниково сажаљење и нежност, а дечја непосредност - дивљење. У суровом свету дете највише пати - због беде, ратова, али и због фрустрирајућег васпитања. Неправедно друштво, преко породице и школе, настоји да у детету уништи урођени смисао за лепо, сву спонтаност и оригиналност (Детиғство, Лов на дете, Лениваи), и начини од њега сиву личност, каква је потребна друштву у коме постоје они

...који у подрумима праве наливпера којима

ће други писати да је све у најбољем реду.

Мало има песника који с толико љубави, а без покровитељства, пишу о животу трудбеника:

\footnotetext{
Људски труд

није леп младић с осмехом

Људски труд нема прави дом
} 


$$
\begin{aligned}
& \text { он заудара на рад } \\
& \text { плућа су му болесна } \\
& \text { зарада мршава... }
\end{aligned}
$$

Човек са улице, таксиста, водоинсталатер, стаклар, продавачица цвећа, скитница, мали чистач ципела, докер, фабрички радник - јунаци су Преверових песама, минијатурних лирских драма, а њихове велике туге и мале радости стална су песникова преокупација.

Позорница ових лирских драма је Париз, али, најчешће, туристима мало познати Париз сиромашних четврти и радничких предграђа. Ту је, пре свега, драги стари „Панам» детињства, VI арондисман, са Луксембуршким парком, Тргом Сен Силпис, Сенском улицом и Улицом Биси, затим сиромашна четврт Гут д’о, у којој живе највећа сиротиња и страни радници, сиво радничко предграђе Обервилије и родни Неји на ивици Булоњске шуме. Булоњска шума и Монсури најдражи су Преверови паркови, јер највише личе на слободну природу. Он не воли Версај и Тиљерије са њиховим геометријским алејама, као што не воли ни велелепна здања. Тријумфална капија, Трг слоге, Инвалиди, Трг Карузел имају изразито негативну конотацију у Преверовој поезији, вероватно највише зато што су подигнути у славу оружја. Превер воли Богородичину цркву и Велику палату, грађевине које леже на обалама песникове љубимице Сене, „која је као живо биће”. Превер воли и далеке градове и реке: раднички Лондон, Њујорк, с црначким Харлемом и Бродвејем, Темзу, Мисисипи и Амур - реку Љубав, као што воли речицу Морле и паћенички Брест из своје постојбине Бретање.

Као и Бодлер, и Превер је песник градског пејзажа у коме се осећа стално човеково присуство, јер Превера занима само човекова судбина. Природа сама по себи не 
заузима много места у његовом делу. Најинтензивнији доживљај природе у Преверовој поезији је посредан, преко Ван Гогових слика у песми Винсентова тужбалица, опис врелог провансалског предела, са сунцем које се врти као „полудела наранџа». Томе се не треба чудити кад се зна колика је Преверова љубав према сликарству. Своме омиљеном сликару, Паблу Пикасу, Превер је посветио две велике песме, које представљају не само апотеозу Пикасовог сликарства, већ и својеврсну естетику и поетику. Овим песмама близак је и текст Како начинити портрет птице, који је и песма и мали трактат о проблему надахнућа и рада на уметничком делу.

Превер воли модерно сликарство: после Пикаса, Миро је његов најомиљенији сликар. Од савремених музичара Преверову пажњу привлаче композитори ван свих школа: Ерик Сати (Satie) и Карл Opф (Orff). И Сатију и Орфу заједничке су склоност ка музичком хумору, једноставност мелодијских линија и извесна архаичност. Преверова поема Кармина бурана (инспирисана истоименим Орфовим ораторијумом) права је химна музици коју песник назива „сунцем ћутања”.

Иако иконокласт и, као и његови пријатељи надреалисти, крајње резервисан према традицији, Превер има своје омиљене писце и дела. Ту су, пре свега, Хиљаду и једна ноћ, авантуристички романи XIX века (Ежен Си: Тајне Париза) и Прустово Трагане за изгубленим временом. Затим песници: Нервал, Лотреамон, Алфонс Але, Алфред Жари (Jarry). Међу њима слободоумни енглески песник и сликар Вилијам Блејк заузима посебно место (Свадбе и гозбе). Од савременика Превер нарочито цени Анрија Мишоа (Michaux), песника и сликара који се, као и он, не уклапа ни у какве категорије.

Ако је, по речима Сент Бева, „Ламартин узео небо, Иго земљу, Бодлер пакао», онда би се за Превера могло рећи да је узео свакодневицу. Превер је ненадмашан као 
песник свакодневице. Само истински мајстор као он може употребом најједноставнијих речи у опису тако баналног призора као што је доручак да постигне ефекат истински трагичног. Као што се од додира руке митског краља Миде све претварало у злато, тако под Преверовим пером и најтривијалније ситуације ${ }^{7}$ постају поезија. Поезија је за Превера враћање изворима. Изворима живота, звука, речи, слике. У чувеној песми Странииа из вежбанке, која је, у ствари, Преверов песнички програм, два и два престају да буду четири, а пред задивљеним дечјим очима руше се зидови.

И стакло опет постаје песак

мастило постаје вода

клупе постају дрвеће

креда постаје литица

a перо опет птица.

Ова песма је несумњиво и алегорија поезије и уметности уопште, њиховог најплеменитијег задатка - враћања изгубљеног идентитета стварима и бићима.

Ако је тачно да је Преверова поезија у свом првом слоју свима доступна, чиста је заблуда да је Превера увек лако пратити и дешифровати вишезначност његовог стиха. Мада неки критичари игноришу утицај надреализма на Превера, тај утицај је, по нашем мишљењу, веома значајан, као што није незанемарљив ни Преверов утицај на надреалисте.

Преверово надреалистичко искуство је онај одлучујући метал који легуру његове поезије чини тако сјајном. То искуство је, не заборавимо, двоструко. Поред дружења са Андреом Бретоном и песницима из његове

7 Колико је то тешко, најбоље показује пример парнасовског песника Копеа: његови Обични туди, уместо да буду дирљиви, смешни су у својој сладуњавости и баналности. 
групе (нарочито са Кеноом), Превер је блиски пријатељ надреалистичког сликара Ива Тангија, а сарађује и са Максом Ернстом, једним од највећих сликара надреализма. Преверова естетика носи печат надреализма, али у њој има готово романтичарске сетности. За разлику од надреалистичке поезије, која је церебрална, Преверова поезија има много топлине са примесом туге, јер мисао о неповратној пролазности свега песника никада не напушта. Утицај надреалистичког поступка, аутоматског писања, видљив је у набрајањима која су честа у Преверовој поезији. У њима долази до пуног изражаја његова вербална инвенција. Најбољи пример за то је песма Поворка, у којој се једноставном пермутацијом делова реченице постиже изванредан утисак:

Стараи од злата са сатом у ирнини

Лучка краљица са енглеским радником

Морнари јавног реда са чуварима на пучини

Неустрашиви ћуран са хусаром на подварку

Змија за кафу са млином за звечарку

У изврсној песми Инвентар, једноставним ређањем асоцијација постижу се најнеочекиванији ефекти. Поред асоцијација речи, у Преверовој поезији постоје и асоцијације слика, од којих Превер вешто прави литерарне колаже користећи се техником, сличном техници сликарског колажа.

Рене Бертеле, песников издавач и пријатељ, човек који је открио Преверову поезију, заслужан је за откриће Преверових колажа. Он сведочи да се Превер колажом бавио откад је почео да пише песме, то јест од почетка тридесетих година. Као што Преверова прва збирка песама, Речи, представља суму петнаестогодишњег песничког искуства, тако су и Преверови колажи, објављени први пут у књизи песничких тек- 
стова 3брда-здола (Fatras, 1966), рад већ зрелог ликовног уметника. Затим долазе нове књиге Преверових колажа: Маштаюа (Imaginaires, 1970), Слике Жака Превера (Images de Jacques Prévert, 1973. и Преверови Превери (Les Prévert de Prévert, 1982).

За разлику од Макса Ернста, ${ }^{8}$ који жели да постигне хармонију разнородних елемената колажа, Превер, напротив, инсистира на првобитној хетерогености, на шоку који произлази из неочекиваног споја, често сукоба, наизглед неспојивих ствари. На Преверове колаже може се у пуној мери применити чувена Лотреамонова реченица коју су надреалисти толико волели да наводе: „Лепо као случајан сусрет шиваће машине и кишобрана на столу за сецирање." Као што је у својим песмама употребљавао обичне речи, за своје колаже Превер се користи свим доступним материјалом: разгледницама, фотографијама, исечцима из часописа, гравирама, репродукцијама чувених слика, илустрацијама из разних књига и анатомских атласа, самолепљивим дечјим сличицама. Тим хетерогеним материјалом Превер се служи као и језичким клишеима у својој поезији: новим комбинацијама познатих појмова и слика он „уништава” тривијалност свакодневице, он је „онеобичава”, како би рекли руски формалисти. Духовито, понекад дрско, често нежно, Превер сликар ${ }^{9}$ разграђени свет предмета спаја у нову целину, стварајући нову лепоту, као што чини и Превер песник у Светковини ствари:

На немогућем раскрићу непомичности гомила непокретних ствари не престаје да дрхти и да игра

8 Његова Жена сто глава (Femme 100 têtes, 1929) означава улазак колажа у историју сликарства.

9 Пикасо Преверу: „Ти не умеш ни да сликаш ни да црташ, али ти си сликар." (Les Prévert de Prévert, стр. 15) 


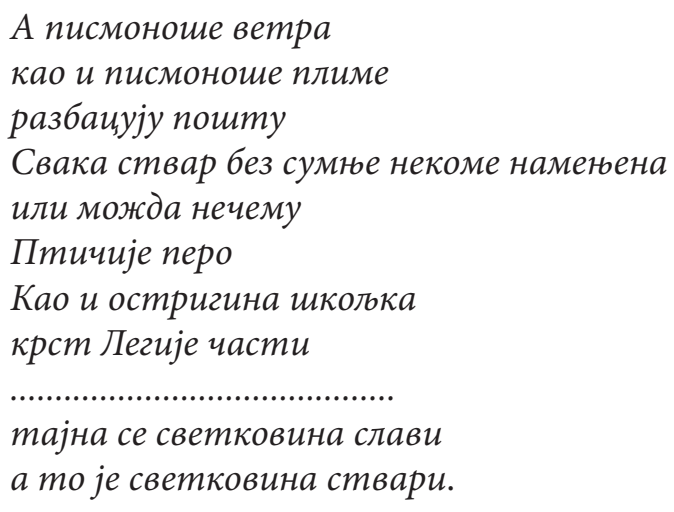

Преверови колажи имају, што је разумљиво, много више књижевних елемената него што их иначе имају сликарски колажи. Пре свега, у Преверовим колажима наслов игра значајну улогу, нарочито кад је ироничан. Осим тога, позадина и распоред фигура имају нечег сценографског. Као и у многим песмама, уметникова пажња је концентрисана на фабулу, „причу». За Превера, очигледно, важно је шта, а не како ће изразити, и за то су му добри сви начини изражавања: „Слика се може исказати песничким средствима, може се направити маказама, ножевима, било чиме.» ${ }^{10}$ Превер је уметник са два начина изражавања'11 која се обје-

10 Превер у интервјуу датом Швајцарској РТВ 1961.

11 Превер, разуме се, није једини књижевник који се бавио ликовном уметношћу. И пре њега, у Француској и другде, било је писаца који су се успешно бавили сликарством. Од нефранцуза, споменимо само чудесног Вилијама Блејка и нашег Ђуру Јакшића. У Француској листа писаца-сликара није мала. Међу њима, на првом месту треба споменути Виктора Игоа, чији цртежи по снажном визионарству не заостају за његовим најбољим песмама ониричне инспирације. Уз зњега треба навести имена двојних стваралаца: Ежена Фромантена, Макса Жакоба, Жана Коктоа, Жана Брилера-Веркора и Анрија Мишоа, остављајући по страни талентоване аматере какви су били Мисе или Бодлер.) 
дињују у трећем: филму, који је спој слике и звука. Пре него што се прославио као песник и афирмисао као сликар, аутор колажа, Превер је постигао изузетан успех својим сценаријима и дијалозима за чувене филмове Децза раја и Вечерни посетиоци. Утицај филма на Преверову поезију је очигледан. Шта су друго Доручак или Сенска улииа до мале филмске драме у којима је готово све подређено анализи покрета једне, односно двеју личности. Детаљнија анализа открила би колико је утицај филмског стила на Преверову поезију дубок: слике које се стапају, углови посматрања који се мењају.

Ипак, за Превера пре слике долази реч. ${ }^{12}$ Он је изговара, пише. Ослушкује је. И песма се понекад рађа готово сама из себе, из звучне анализе речи, из буквалног значења израза (На зуб), па чак и из низања погрдних речи (Мацина трава). Занимљива је и оригинална Преверова игра општим местима и клишеима. Он у поезији постиже оно што је Флобер постигао у прози. Мада у Преверовим песмама нема класичне версификације, риме и асонанце су многобројне чак и у самим стиховима. Преверова поезија је звучна и пуна ритма. Довољно је упоредити први и други део песме Песма пужева који иду на погреб да бисмо се уверили колико је ритам прилагођен значењу: у првом делу равномерни ритам погребног марша, у другом - весели убрзани ход поднапитих пужева :

На погреб мртвог тиста

Кренула пужа два

Носе кућице ирне

Око рогова флор

12 Геатан Пикон примећује: „Превер пре говори него што пише: он има више дикцију него стил.» Op. cit. 


\begin{abstract}
A вечер је тепа
Кад је пуна флаша

Дивна вечер летьа

И два пужа нама

Bраћају се кућu

После доста чаша

Малко посрћући

Одлазе пресрећни

Тронути дубоко

Месеи, бди над нима

На небу високом.
\end{abstract}

Преверове песме пружају обиље примера врло успелих алитерација и парономазија ${ }^{13}$, игри речи, намерних лапсуса, двосмислености и искривљавања значења. Из језика Превер извлачи скривени хумор, који је час црн и убитачан, час ведар и нежан.

Доминантна боја Преверове поезије је црвена - боја љубави и смрти, боја крви. Превера опседа крв која тече потоцима купајући несрећну земљу (Песма у крви) или, топла, капље из ране (Подигнута палииа, То тице тубави опасно и нежно). Крв у постељи породиље као почетак, и тамна мрља згрушане крви на асфалту као крај живота. Две омиљене личности Преверове поезије су река и сунце. Реку најрадије приказује у сиво праскозорје, сунце као ватрену куглу или наранџу. Наранџа је песников омиљени плод, симбол живота, саучесник љубавника, „сунце ноћи» (Наранца). Стари, лепи симбол слободе, птица, тугује, лепрша и лети Преверовим песмама. Весела или рањена, распевана или на умору, она у Преверовој поезији прераста у један још универзалнији знамен - симбол човечанства, људске наде и живота уопште.

13 Реторичка фигура у којој се ређају, једна поред друге, речи сличног звука, а различитог значења. 
Без претеривања, могло би се рећи да животиње играју улогу која је по свом значају блиска оној коју оне имају код Лафонтена. У Преверовом бестијаријуму птица, слон и магарац заузимају привилегована места. За њима долазе остале животиње: коњ, жирафа, камила, ној, зец, пас.

Поред већ познатих значења, птица у Преверовој поезији има и друге симболичке функције. Ласта је свевидећи мудри сведок, пун љубави и саосећања за напаћене (Догађај), сојка (Поздрав птици) постаје готово митска птица, благонаклоно божанство које се брине о малим људским радостима. Сасвим ретко симбол птице има негативну конотацију (Птице бриге). Слон и магарац су оличења доброте и мудрости. Песнику они служе да истакне безмерност људске глупости. Жирафа, зец и друге животиње представљају у Преверовом делу аутентични живот, који он супротставља измишљеном и књишком, лажном животу. Коњ и пас човеку су најближе животиње, чију љубав он бестидно злоупотребљава, док мачка има амбивалентну улогу. У Подигнутој палици мачак је брижни саветник, у песми Мачак и птииа - оличење покварености.

Дрвеће, коме је Превер посветио целу збирку песама, предмет је готово паганског обожавања. Атеист Превер нас учи да дрвеће има душу (његово омиљено дрво је маслина). Први услов човекове среће је да се ослободи своје нарцисоидности и покуша да схвати живи свет око себе. Он мора да научи да поштује не само другога човека, већ и животиње, биљке, реке, јер су оне његова спона са целокупношћу света. Превер нас учи да волимо. 


\section{Литература}

Jacques Prévert : Euvres complètes, 2 vol, Pléiade, Gallimard, Paris, 1992-96.

Georges Bataille : De lâge de pierre à Jacques Prévert

Raymond Queneau : Jacques Prévert - le bon génie, 1952.

Arnaud Laster : Prévert: Paroles, 1972.

Henri Lemaître : Aventure littéraire au XX siècle, 1984.

Danièle Gasiglia Laster : «Paroles » de Jacques Prévert, 1993.

Carole Aurouet : Prévert, portrait d'une vie, 2007.

\section{Преводи поезије Ж. Превера на српски}

Одабрана дела, 3 књиге (Речи, Велики пролећни бал, Сена је срела Париз). Превод, поговор и коментари Радивоја Константиновића, 1982.

Чари Париза;Чари Лондона. Избор и превод Николе Трајковића, 1964.

Избор. Изабрао и превео Данило Киш, 1967.

Поезија, (наслов оригинала: Histoires). Превео Александар Ристовић, 1969.

Неке ствари и остало. Изабрао и превео Мирослав Караулац, 1977. 